\title{
Family Poultry (FP) as a Tool for Improving Gender Equity and Women's Empowerment in Developing Countries: Evidence from Bangladesh
}

\author{
Soshe Ahmed, Maksuda Begum, Afia Khatun, Md. R Gofur, Md. TA Azad, Aurangazeb Kabir, \\ and Tasmin S. Haque
}

\section{ABSTRACT}

The study assessed the integrated gender issues of family poultry production in developing countries with evidence in Bangladesh. The result draws attention to the widespread acknowledgment of the critical roles of gender in family poultry production system. The results show that women hold the maximum of the ownership $(90.58 \%, p=0.0001)$ and responsible for the caring of $(93.94 \%, p=0.0001)$ family poultry in Bangladesh, likewise other developing countries. The result reveals that women control over the decisionmaking for the selling of eggs and birds in Bangladesh. Women mostly $(\mathbf{9 4 . 5 8 \%})$ hold the knowledge useful in the prevention and treatment of poultry illness; however, their role was found low $(3.46 \%)$ in buying medicine and vaccines for poultry as compared to men $(\mathbf{9 6 . 5 4 \% )}$ ) in Bangladesh. The findings show that women were nearly two times more willing than men to adopt improved rearing technologies related to family poultry production. Both women and men are impacted indifferently by lower adoption of scientific poultry-keeping technologies. Women are independently facing more problems in access to knowledge, training, services, marketing systems, and financial services related to family poultry production. Despite having many limitations, it is clear that family poultry empowers women through asset accumulation and increasing their decision-making ability in the families and the broader community. The study also highlights the necessity of considering an engendered approach in policy and operational level for the family poultry development.

Keywords: Constraints to family poultry, Engendered approach, Gender disparities, Ownership of family poultry.

\section{INTRODUCTION}

The role of poultry in poverty alleviation along with food security and promotion of gender equality in developing countries is documented by many researchers [1]-[7]. Family poultry provides meat and eggs with high quality, digestible protein for immediate home consumption and sale for income generation for the families [8], [9]. Family poultry development can improve the resource-poor farmers' nutrition security and livelihoods [9], [10]. Family poultry (FP) keeping is a widely practiced activity in rural and periurban areas in developing countries [11]-[13]. About $80 \%$ of rural families in Bangladesh keep one or more poultry species
Submitted : February 20,2021

Published: March 14,2021

ISSN: $2684-1827$

DOI: 10.24018 /ejfood.2021.3.2.251

Soshe Ahmed*

Associate Professor, Dept. of Veterinary and Animal Sciences, University of Rajshahi, Bangladesh.

(e-mail: soshe.ahmed@gmail.com) Maksuda Begum

Department of Poultry Science, Facultyof Animal Science and Veterinary Medicine, Sher-e-Bangla Agricultural University, Bangladesh.

(e-mail: maksudashovona80@gmail.com) Afia Khatun

Dept. of Veterinary and Animal Sciences, University of Rajshahi, Bangladesh.

(e-mail: afiakhatuns@gmail.com)

Md. R Gofur

Dept. of Veterinary and Animal Sciences, University of Rajshahi, Bangladesh.

(e-mail: royhangm@ gmail.com)

Md. TA Azad

Dept. of Veterinary and Animal Sciences, University of Rajshahi, Bangladesh.

(e-mail: thoufic@ru.ac.bd)

Aurangazeb Kabir

Dept. of Veterinary and Animal Sciences,

University of Rajshahi, Bangladesh.

(e-mail: aurangak@yahoo.com)

Tasmin S. Haque

Department of Anthropology, University of Rajshahi, Bangladesh.

(e-mail: soma.haque3246@gmail.com)

*Corresponding Author 
husbandry practices, understanding gender relations and their implications concerning family poultry production are crucial for developing appropriate and successful interventions. Applying a "gender lens" to identify and address women's and men's roles and priorities related to family poultry production is important for determining the most effective use of the resources. Evidence from several investigations shows that livestock programs' development initiatives found successful when working with the most appropriate beneficiaries [18], [19]. There is evidence that women's labor and responsibilities in animal production remained underrecognized and underappreciated during designing and implementing livestock development programs in many cases [20]-[22]. Understanding gender roles and responsibilities can lead to more effective design and implementation of development programs. Knowing who has decision-making power over livestock and poultry in the household and community can enable animal health practitioners to identify ways of building on valuable human capital. Understanding men's and women's different decision-making powers and negotiating strategies can help design more effective family poultry production initiatives. In particular, development interventions should be adequately sensitive to social and cultural issues, especially considering gender-based constraints, needs, and opportunities [6], [10], [23]-[26]. Gender analysis should be carried out to identify genderspecific constraints and opportunities to access resources, information, and services related to family poultry production. Therefore, development initiatives should be focused on targeting specific needs and interests of the particular groups to reduce gender inequalities and ensure equitable and sustainable benefits to both men and women [27]-[29]. Addressing gender in family poultry development programs is essential from the sustainability point of view. Overall, it is believed that developing gender-sensitive programs can provide an opportunity for households to increase their village poultry flock, eventually their income and nutrition security. Earlier research into family poultry (FP) development usually narrowly focused on technical aspects with very little or no attention paid to the broader gender aspects. The majority of the village poultry development initiatives had not addressed and integrated gender issues and perspectives in their work. Also, there is limited gender-disaggregated data on gender roles and contributions to family poultry production systems. Therefore, the study is taken to gather gender-disaggregated data that provide a precise picture of the gender dimensions in family poultry production. The proposed research determines the utilization and ownership pattern of family poultry in households. The study discovers the gender roles and responsibilities concerning family poultry production. The findings also reveal the decision-making authority over the poultry they manage in the family and their benefits. The study determines the gender-specific constraints, needs, and opportunities of family poultry production. Additionally, the research focuses on assessing the necessity of the engendered approach in family poultry development programs and policies.

\section{MethodOLOGY}

\section{A. Research Design}

In this research, we use both primary and secondary data sources. The study covers a wide range of literature reviews on family poultry production in developing countries worldwide. We collected primary data through a crosssectional household survey using two complementary approaches: in-depth interviews and focus group discussions (FGDs) from August to October 2019 from the north-western part of Bangladesh. We gathered secondary information through a wide range of literature reviews from different published documents such as journal articles, referral books, conference papers, statistical yearbooks, and other organizational reports.

\section{B. Sampling and Data Collection}

In this study, we adopted a multi-stage sampling technique. We chose Two (02) administrative divisions (Rajshahi and Rangpur) of Bangladesh for primary data collection using a purposive sampling technique. Rajshahi division lies within $23^{\circ} 48^{\prime}$ and $25^{\circ} 16^{\prime}$ north latitudes and $88^{\circ} 01^{\prime}$ and $89^{\circ} 48^{\prime}$ east longitudes. Rangpur division lies in between $25^{\circ} 20^{\prime}$ and $26^{\circ} 37^{\prime}$ north latitudes and in between $88^{\circ} 50^{\prime}$ and $89^{\circ} 53^{\prime}$ east longitudes. Eight (08) districts, four (04) from each division, were selected randomly. Thirdly, two villages from each district having comparatively more domestic poultry by the families set purposively with the consultation of the district livestock officer of the respective district; thus, we took sixteen villages were taken for the primary data collection. In the last stage, we selected poultry-keeping households using a cluster sampling technique.

The respondents interviewed included $n=924$ family poultry owners to collect the households' quantitative data in their settings. We used both close-ended and open-ended questions to the respondents. We conducted in-person interviews with poultry owners, capturing poultry ownership, labor contributions to the poultry-keeping activities, and family poultry's utilization pattern. Additionally, we collected information on family poultry keeping, disease awareness of poultry and willingness of technology adoption by the poultry keepers, and control over the poultry assets and decisionmaking authority. We conducted 16 focus group discussions (FGDs) with poultry keepers to investigate the genderspecific constraints, needs, and possible family poultry production opportunities. Participants from similar experiences were brought together into the group discussions. In our meetings, we tried to focus on the women and men's constraints involved in the family poultry keeping. Allied to this, we covered the following topics: access to technologies, knowledge, extension services, other development interventions, knowledge on poultry vaccination and access to veterinary services, participation in poultry marketing systems, and access to financial services. We investigated the gender-specific needs and possible opportunities for family poultry production through group discussions with poultry keepers.

\section{Data Analysis}

The quantitative data are summarized using descriptive statistics, whereas the qualitative data were summarized by frequency count and percentage (\%). Results of the 
qualitative and quantitative data are presented as graphs, charts. Key messages from interviews, direct observation, and the group discussion are summarized intables.

The analysis performs Chi-square tests to examine the association of gender with other factors for poultry disease awareness. The data were managed in Microsoft Excel 2007 and were analyzed using the software SPSS version 24.0.

In this study, the null and alternative hypotheses are as follows:

$H_{0}$ : Two variables are statistically independent versus

$H_{1}$ : Two variables are not statistically independent.

To test this, we measure the discrepancy of observed and expected frequencies. The Pearson Chi-square test is done as follows:

Pearson $\chi^{2}=\sum_{i} \sum_{j} \frac{\left(O_{i j}-E_{i j}\right)^{2}}{E_{i j}}$

where, $O_{i j}$ and $E_{i j}$ are the numbers of cases observed and expected with level $i$ of variable 1 and level $j$ of variable 2, respectively.

In this research, we used the multiple logistic regression model to identify the socio-economic factors determining women's awareness about birds' disease. In our study, the multiple logistic regression model was formulated as follows:

$$
\log \left(\frac{p}{1-p}\right)=\beta_{0}+\beta_{1} X_{1}+\beta_{2} X_{2}+\beta_{3} X_{3}+\varepsilon
$$

where

$\mathrm{p}=$ "the probability that women are aware of the disease of birds";

$X_{1}=$ Educational status;

$X_{2}=$ Basic ownership;

$X_{3}=$ Take-care of poultry;

$\varepsilon=$ error term.

\section{RESULTS}

\section{A. Ownership, Roles, and Responsibilities over the Family Poultry Production}

Surveys carried out in some developing countries revealed thatwomen tend to own the direct ownership of family poultry in developing countries worldwide and have more control and decision-making authority over poultry in the households [30]. Studies in several sub-Saharan African countries revealed that backyard chickens are owned and managed by women in the rural areas [31]-[35]. Especially in rural areas of developing countries, poultry is frequently under the independent control of women. Men are basically involved in constructing a shelter for the chickens [16], [17]. Evidence from Zimbabwe and Ethiopia showed that village chickens exclusively to women [36], [37], and responsible for the birds' care, and selling of chickens and eggs. There is consistent evidence that women carry out most of the village chicken production [38]. The above scenario is, to some extent, supported by our survey in Bangladesh. Table 1 provides descriptive data from the field study in Bangladesh. We found that the distribution of domestic poultry ownership is more a women's domain $(90.58 \%)$ compared to men $(9.42 \%)$. We revealed that women contributed to maximum (93.94\%) responsibilities for birds' caring compared to men.

TABLE 1: OWNERSHIP, GENDER-SPECIFIC LABOR CONTRIBUTION, AND CONTROL OVER THE FAMILY POULTRY (FP) PRODUCTION SYSTEM IN BANGLADESH $(\mathrm{N}=924)$

\begin{tabular}{|c|c|c|}
\hline \multirow[b]{2}{*}{ Variables } & \multicolumn{2}{|c|}{ Gender } \\
\hline & $\begin{array}{l}\text { Female } \\
n(\%)\end{array}$ & $\begin{array}{l}\text { Male } \\
n(\%)\end{array}$ \\
\hline Take care of poultry & $868(93.94)$ & $56(6.06)$ \\
\hline Disease awareness of birds & $874(94.58)$ & $50(5.42)$ \\
\hline Buy/bring medicine and vaccines & $32(3.46)$ & $892(96.54)$ \\
\hline Basic ownership of the poultry & $837(90.58)$ & $87(9.42)$ \\
\hline $\begin{array}{l}\text { Control over the selling eggs and } \\
\text { birds* }\end{array}$ & $243(84.37)$ & $45(15.62)$ \\
\hline Willing to technology adoption & $753(89.96)$ & $38(43.67)$ \\
\hline
\end{tabular}

*68.83\% $(n=636)$ of the total 924 households consume their eggs and birds. Source: Author's calculation based on a survey in Bangladesh, 2019.

\section{B. Decision-making, Control over the Family Poultry Assets, and Women's Empowerment}

There is a consensus around the developing countries that the women look after the family poultry and control the earnings from eggs and birds [30], [38]-[40]. Our survey result in Bangladesh also found that women hold the maximum $(84.37 \%)$ control over the poultry eggs and birds they produce in the family (see Table 1 ). The present study demonstrated that women tend to regulate eggs and birds' merchandising and manage financial gain. Family poultry ownership is increasing women's decision-making and economic power within the household and in the community. It is also a source of cash and can open up access to credit to the women. It is argued that owning, controlling, and benefiting from family poultry production increases the women's self-esteem within the household and in the community [41].Studies have shown that promoting native chicken production empowers rural women [42]. The role of family poultry in food security, harness income, employment creation, poverty alleviation, and the promotion of gender equality in developing countries is evident [5], [43]. Earlier study by Gueye [6] have explored that women often start by investing in livestock and other profitable activities from family poultry's income, which can help women accumulate assets. It is argued that reducing the gender asset gap or putting assets in women's hands is critical to have positive outcomes. There is a link between women's ownership of assets and their bargaining power and their decision-making in household issues [44], [45]. Evidence shows that womenmanaged assets and income is associated with child nutrition and education, greater access to health services, which leads women in a privileged position in the family [7], [40], [45][47]. Reducing the gender asset gap to empower women is significant to achieve Sustainable Development Goal 3 [48]. However, village poultry production systems are a significant income-generating activity for women, and $90 \%$ of the women's income is channeled back into their households or local communities [49], which may enhance the livelihood through the empowerment of women. 


\section{Gender Response to Poultry Disease Awareness and} Technology Adoption

Table 2 also summarizes the poultry disease awareness and the willingness to adopt the technologyby women and men in Bangladesh. Our findings illustrated that most women $(94.58 \%)$ hold the knowledge useful in preventing and treating poultry illness. Women were more familiar with the terms that described diseases across categories, yet they may not have direct access to veterinary services for numerous reasons. Women's knowledge of poultry disease terms was comparable to that of men. This result indicated that veterinary extension activities related to disease prevention need to improve their capabilities. Though women are the fundamental owner of domestic poultry and found aware of poultry diseases; however, their role found low (3.46\%) for buying medicine and vaccines, as did men (96.54\%). The observation indicated that women $(89.96 \%)$ tend to adopt poultry rearing technologies surpassing double that of men (43.67\%). Therefore technology adoption for family poultrykeeping needs to evolve with local people over a long period. Other evidence suggests that women tend to adopt technologies earlier than men and are consequently well placed to act as catalysts for technology change in livestock production [22].

TABLE 2: LOGISTIC REGRESSION DETERMINING THE GENDER-SPECIFIC DISEASE AWARENESS OF FAMILY POULTRY IN BANGLADESH

\begin{tabular}{|c|c|c|}
\hline Variable & OR $(95 \% \mathrm{CI})$ & $\mathrm{p}$-value \\
\hline \multicolumn{3}{|c|}{$\begin{array}{l}\text { Educational status } \\
\text { (Ref: }>\text { Secondary) }\end{array}$} \\
\hline Illiterate & $13.065(1.751-97.509)$ & 0.0122 \\
\hline Primary & $36.674(5.597-240.294)$ & 0.0002 \\
\hline Secondary & $28.179(3.536-224.579)$ & 0.0016 \\
\hline \multicolumn{3}{|c|}{$\begin{array}{l}\text { Basic ownership } \\
\text { (Ref: Male) }\end{array}$} \\
\hline Female & $10.968(3.554-33.849)$ & $<0.0001$ \\
\hline \multicolumn{3}{|c|}{$\begin{array}{l}\text { Take care of poultry } \\
\text { (Ref: Male) }\end{array}$} \\
\hline Female & 315.307 (100.835-985.951) & $<0.0001$ \\
\hline
\end{tabular}

Source: Authors' calculation from survey data, 2019.

From the analysis, we found that the odds ratio of being aware of the disease of birds is 13.065 times greater $(\mathrm{p}<0.0001)$ for illiterate than for the people with secondary education (Table 2). Similarly, the odds ratio of disease awareness of birds is 36.674 times greater $(p<0.0001)$ for primary educated than for the people of secondary education. We noted that education levels and disease awareness of the poultry keepers were negatively associated. Peoples with higher education had a lower level of poultry disease awareness because of their less dependency on family poultry for livelihood issues. Poultry disease awareness of the female owner was 10.968 times greater $(\mathrm{p}<0.0001)$ compared to the male owner (see Table 2). Also, we found the odds ratio of disease awareness of birds 315.307 times greater $(p<.0001)$ for a female caretaker of poultry than for male caretakers. Regarding involvement in taking care of family poultry, it implies that the higher the woman's participation, the more her involvement in disease awareness and control options. It is recognized that even though the significant involvement of women in dealing with poultry disease control, their access to information and extension messages is more likely to be limited in developing countries due to various reasons [16]. The present findings illustrated that women and men have different roles in disease prevention and control options. Governments must address cost-effective prevention and control of significant animal diseases involving men and women in formal and informal capacity building processes [18]. The current findings demonstrated the necessity of planning disease prevention and controlling family poultry diseases and gender lines.

\section{Utilization Pattern and Perspective of Family Poultry (FP) Keeping}

Table 3 shows the utilization of pattern eggs and birds from family poultry and owners' perspectives of family poultry keeping in Bangladesh. In most cases, we observed that domestic poultry $(68.8 \%)$ and their eggs $(97 \%)$ are used inhome consumption. The principal utilization of eggs and birds of domestic poultry indicated the non-commercial use of the family poultry in Bangladesh. However, $31.2 \%$ of the families sold their birds rather than home consumption. The study examined the priorities and concerns of household poultry keeping. Our findings found that the male and female had shared and separate objectives or interests in domestic poultry. The critical perspectives of family poultry keeping in Bangladesh are shown in table 3. We noted that overall, $68.83 \%$ of the families thought of poultry keeping was as primarily contributing to the family nutrition, $18.18 \%$ of the owners keep poultry to meet household expenditures, $9.19 \%$ to meet sudden emergency needs.

And $3.78 \%$ of the families keep poultry as a way to further invest in other income-generating activities. Numerous studies carried out in some developing countries revealed that perspectives of keeping family poultry as a means of livelihood diversification, capital accumulation, way to meet sudden needs of the family a household savings, further investment, and insurance [50], [51].

TABLE 3: DISTRIBUTION OF RESPONSES TO THE PRINCIPAL UTILIZATION OF EGGS AND BIRDS FROM FAMILY POULTRY AND PERSPECTIVES OF FAMILY POULTRY KEEPING (N=924)

\begin{tabular}{ccccc}
\hline \multicolumn{4}{c}{ Utilization of eggs and birds } \\
\hline \multirow{2}{*}{ Category } & Home Consumption & \multicolumn{2}{c}{ Selling } \\
\cline { 2 - 5 } & No. & $\%$ & No. & $\%$ \\
\hline Utilization of eggs & 896 & 97 & 28 & 3 \\
Utilization of birds & 636 & 68.8 & 288 & 31.2 \\
\hline Owners' perspectives of family poultry keeping \\
\hline Category & No. & $\%$ \\
\hline Family nutrition & 636 & 68.83 \\
Household expenses & 168 & 18.18 \\
Sudden emergency needs & 85 & 9.19 \\
Way to further investment & 35 & 3.78 \\
\hline
\end{tabular}
Source: Survey data, 2019.

\section{E. Gender Disparities in Access to Productive Resources and Services}

Contemporary studies have explored consistent gender disparities in access to and benefits from technologies, services, and other family poultry production interventions across developing countries. Women have more inadequate control over a range of productive resources and services than men [30], [46]. Advancing market access by the producers is one of the most strategic pillars of any program [52]. It is argued that women face several constraints in participating in marketing systems due to their imprecise marketing networks compared to men [53]-[55]. It is evident that women are less exposed to extension messages, even with the activities are related to them [16]. Even though women are involved in 
dealing with poultry disease control, there is still a very high gender imbalance among veterinarians and extension workers in developing countries where most service providers are predominantly male. The findings from group discussions summarize in Table 4 show the gender-specific constraints, needs, and opportunities of family poultry production in Bangladesh.

TABLE 4: GENDER-SPECIFIC CONSTRAINTS, NEEDS, AND OPPORTUNITIES OF FAMILY POULTRY PRODUCTION IN BANGLADESH

\section{Major constraints Priority needs}

- Men and women are impacted indifferently by lower adoption of scientific technologies.

poultry-keeping

\section{- vWomen's insufficient access to} development interventions.
- Training programs to include men and women according to their roles and responsibilities.

- Women should be made specific targets in training for poultry production and care and disease prevention options.

- Gender sensitization increases women's accessibility to information, uses women-friendly innovative methods in extension activities, and introduces gender-sensitive development initiatives. Anticipated opportunities

- The adoption of modern technology in indigenous husbandry practices can suitably be used in FP production systems.

- Awareness building among the poultry keepers on improved and scientific poultry rearing practices.

- Improvement in access to necessary information by the women.

- Consistent extension service systems to maximize the benefit from those activities.

- More participation of women in family poultry development programs.

- Gender equality in livestock services and organizations

- Provision of information and knowledge-tailored to meet the specific needs of the target groups.

- Less participation of women in poultry marketing systems and limited access to financial services.
- Women's participation in poultry value chains.

- Initiation of farmers groups or associations at the community level.

- Working in groups can help women to retain control and more efficient use of income generated from family poultry production.

- A marketing system accessible to women is the key to guaranteeing a better price for their family poultry.

- Dismantle barriers and promote women's access to financial service facilities at the community level.

\footnotetext{
- Both women and men are lacked knowledge of poultry vaccination and facing difficulty in access to veterinary services.

- Introduction of suitable vaccines with ensuring the availability in the localities

- Awareness building and training program for men and women on poultry vaccination

- Creation of community-based animal health workers to include mostly women as much as possible.
}

- Capacity and awareness building on poultry vaccination and the provision of services to prevent and combat poultry diseases.

- Promotion of primary healthcare, vaccination, and de-worming programs by the community health workers to ensure availability of important services at community level.

Source: Analysis from focus group discussions, 2019.

\section{DISCUSSION}

Diverse perspectives of genders are valuable to get benefit from the family poultry sector. Decision-makers and planners often neglect gender roles and responsibilities in their programs and policies. Mainstreaming gender in poultry development initiatives addressing women and men's specific roles and responsibilities can benefit beneficiaries and project implementers. The findings reveal that women keep most family poultry ownership in Bangladesh and developing countries [16], [17], [36], [56]. Likewise, ownership, family poultry keeping is predominantly under the care and management of women. This result is broadly consistent with the findings of African settings [5], [6], [27], [38], [57]. The result illustrated that women tend to regulate the decisionmaking for selling the eggs and birds and manage the financial gain generated from those in Bangladesh. This finding indicates women's empowerment through family poultry keeping. Results in earlier studies also noted that women are often responsible for decision-making on chicken production issues in developing countries [30], [38], [39], [49]. Evidence from empirical findings showed that ownership of family poultry helps women accumulate assets enhancing their economic empowerment through further participation in household decision-making activities [6], [44], [45], [58].

The study indicated that family poultry mostly contributes to household nutrition and income for women in Bangladesh.
The study also illustrates the people's thought of poultry keeping is primarily contributing to family nutrition, family expenditures to meet sudden emergency needs, and ways to invest. Several studies in many developing countries discovered the perspectives of keeping poultry as a means of livelihood diversification, capital accumulation, and meeting the family's sudden needs [50], [51].

In our survey in Bangladesh, we found that women have greater poultry disease awareness compared to men. The result also indicates that education levels and poultry disease awareness of the farmers are negatively associated. The aforementioned is because peoples with higher education have less dependency on family poultry production for their livelihood issues. In Bangladesh, socio-culturally, women's access to information and training continues to be limited and even indirect. The result is consistent with the results of the previous study. For example, poultry keepers have difficulty accessing veterinary care services in Bangladesh, like routine treatment and domestic poultry de-worming was found inadequate and infrequent [14]. As women are mostly responsible for the diagnostic of poultry diseases in the family, they should be involved in poultry health training and interventions. Despite the significant role of family poultrykeeping played by the women, we found that they do not usually buy medicines and vaccines for their birds in Bangladesh. Even though men are reluctant to take care of birds and disease awareness of poultry, they typically purchase medicines and vaccines. Because women usually do 
not go to the markets or outside premises compared to men due to cultural aspects. Therefore, programs should target men and women for training on handling and storing poultry vaccines and performing birds' vaccination. The result indicated that women tend to adopt technologies more than double compared to men in Bangladesh. Evidence from other studies also suggests that women, compared to men, tend to adopt technologies earlier and act as catalysts for the technology change [22]. It is believed that this type of trait of women can pass on in the women's line from mother to daughter. Therefore, the program or project should identify and consider women's specific socio-cultural conditions, needs, and time considerations. Also, the limited mobility and high illiteracy rate of women in rural communities should consider making the project successful.

Data from the present survey in Bangladesh revealed that both men and women are impacted indifferently by lower adoption of scientific poultry-keeping technologies. The empirical findings show that both women and men lack knowledge of poultry vaccination and face difficulty accessing veterinary services.This study also discovers women have reduced access to knowledge, extension messages, poultry marketing systems, and financial services. This result is widely consistent with the results of several contemporary studies conducted in many developing countries. They explored consistent gender disparities in access to and benefits from technologies, services, and other interventions across developing countries [16], [30], [46], [54]. Also, examples from several development projects suggest that women typically face constraints in accessing markets than men for various reasons [20], [59], [60]. Gender-responsive development programs and policies are essential to overcome the gender-specific constraints of family poultry production. Mainstreaming gender in poultry development interventions can benefit primary beneficiaries, project implementers, and other stakeholders by reducing gender disparities in access to productive resources. For example, women's income increases their bargaining power within the family to improve child nutrition, health status, and educational attainment [61]. Evidence showed that women's participation in livestock value chains reduces gender inequalities by expanding their capabilities and opportunities [62]. Examples from different project experiences show that access to capital, knowledge, extension services, and technologies made in lines for women was successful [22], [63]. Many livestock projects found successful when designed based on gender lines [64], [65].

\section{CONCLUSION}

The present study provides a link between family poultry production and widespread gender issues. The study determines the relationship between disease awareness of birds with other factors. The result also underlines the willingness of technology adoption by women and men related to family poultry production. The findings exhibit the decision-making authority over the poultry they manage in the family and their benefits. The study determines the gender-specific constraints and needs of family poultry production and illustrates the possible opportunities. The study draws attention to the necessity of an engendered approach in family poultry development interventions. The survey result in Bangladesh suggests that women own family poultry ownership and carry out most family poultry production activities, except buying vaccines and medicine for birds. This study shows that women tend to be more aware of poultry disease and are willing to adopt the technology. Women hold the maximum control over the poultry they produce in the family and regulate the merchandising of eggs and birds and manage the financial gain. The result shows that women face problems in access to knowledge, training, services, marketing systems, and financial services. Evidence shows that family poultry ownership increases women's decision-making and economic power within the household and in the broader community in developing countries.

The literature reviews in this study show that the engendered approach in programs and policies in livestock development is beneficial in various ways. Hence, men and women should include formal and informal capacity building processes according to their roles and responsibilities related to the family poultry-keeping activities. Family poultry development programs need to adopt women-friendly extension messages with balanced gender representation, culturally appropriate, and easily deliverable at a place and time allowing women's participation. There is a need to establish the gender balance of animal health workers to benefit from female owning farms. It is crucial to design programs consisting of more relevant elements in line with men's and women's needs, priorities, and interests. Commencement of interventions to increase women's access to markets through the value chain is necessary to enhance women's income generation and decision-making ability. Therefore, gender issues should be an integral part of the project design, and operational plans for the development of family poultry.

\section{ACKNOWLEDGMENTS}

The authors gratefully thank the family poultry keepers in the study area for their patience, time, and the information provided during the data collection.

\section{CONFLICTS OF INTEREST}

The authors declare no conflict of interest.

\section{REFERENCES}

[1] Alders, R. (2004). Poultry for Profit and Pleasure. Diversification Booklet No. 3; Agricultural Support Systems Division; Food and Agriculture Organization of the United Nations: Rome, Italy.

[2] Dolberg, F. and Petersen, P.H. Poultry as a tool in Poverty eradication and promotion of gender equality. Proceedings of a workshop; The Danish Agricultural and Rural Development Advisers' Forum: Tune Landboskole, Denmark, 22-26 March 1999.

[3] de Bruyn, J., Wong, J., Bagnol, B., Pengelly, B. and Alders, R. (2015). Family poultry and food and nutrition security. CAB. Reviews, 10, 19.

[4] Dumas, S.E., Lungu, L., Mulambya, N., Daka, W., McDonald, E., Steubing, E., Lewis, T., Backel, K., Jange, J., Lucio-Martinez, B., Lewis, D. and Travis, A.J. (2016). Sustainable smallholder poultry interventions to promote food security and social, agricultural, and ecological resilience in the Luangwa Valley, Zambia. Food Security, 8 , 507-520. 
[5] Guèye, E.F. (2000). The role of family poultry in poverty alleviation, food security and the promotion of gender equality in rural Africa. $\begin{array}{llll}\text { Outlook on } & \text { Agriculture, } & 29, & 129-136 .\end{array}$ https://doi.org/10.5367/000000000101293130.

[6] Guèye, E.F. (2002). Family poultry research and development in lowincome food-deficit countries: approaches and prospects. Outlook on Agriculture, 31, 13-21. https://doi.org/10.5367/000000002101293822.

[7] Meinzen-Dick, R., Behrman, J.A, Menon, P. and Quisumbing, A.R. Gender: A Key dimension linking agricultural programs to improved nutrition and health (Based on 2020 Conference Brief). International Food Policy Research Institute (IFPRI): Washington DC, USA, 2011, pp. 135-144.

[8] Mapiye, C.; Sibanda, S. (2005). Constraints and opportunities of village chicken production systems in the smallholder sector of Rushinga District of Zimbabwe. Livestock Res. Rural Dev. 17, Article \#115http://www.cipav.org.co/lrrd/lrrd17/10/mapi17115.htm.

[9] Miao, Z.H., Glatz, P.C. and Ru, Y.J. (2005). Free-range poultry production-A review. Asian-Australasian Journal of Animal Science, 18, 113-132. https://doi.org/10.5713/ajas.2005.113

[10] Kitalyi, A.J. (1998). Village chicken production systems in rural Africa: household and food security and gender issues. Animal Production and Health Paper 142; FAO: Rome, Italy. http://fao.org/docrep/003/w898e/w8989e00.htm.

[11] Akinola, L.A.F. and Essien, A. (2011). Relevance of rural poultry production in developing countries with special reference to Africa. World's Poultry Science Journal, 67(4), 697-705. http://dx.doi.org/10.1017/S0043933911000778

[12] Fattah, K.A. Poultry as a tool in poverty eradication and promotion of gender equality. In: Proceedings of a Workshop on Poultry as a Tool in Poverty Eradication and Promotion of Gender Equality (Dolberg, F.; Petersen, P.H.; Eds.); Tune, Denmark, 2000, pp. 16-28.

[13] Pym, R. Poultry Genetics and Breeding in Developing Countries. Poultry Development Review; FAO: Rome, Italy, 2013, pp. 80-83.

[14] Ahmed, S., Haque, T.S., Rahman, S., Sultana, M.R., Rahman, M.M., Islam, M.S., Kabir, A., Moni, M.I.Z., Haque, M.H. and Khaton, R. (2019). Loss of Domestic Poultry Due to Flood and the State of Veterinary Care Services in Flood-Prone Areas of Bangladesh. International Journal of Poultry Science, 18, 231237.https://doi.org/10.3923/ijps.2019.231.237.

[15] Saleque, A. "Scaling-up: critical factors in leadership, management, human resource development and institution building in going from pilot projects to large scale implementation - the BRAC poultry model in Bangladesh." Proceedings of a workshop on poultry as a tool in poverty eradication and promotion of gender equality, Tune, Denmark, 22-26 March 1999.

[16] Bagnol, B. (2009). Gender issues in small-scale family poultry production: experiences with Newcastle Disease and Highly Pathogenic Avian Influenza control. World's Poultry Science Journal, 65, 231-240. http://dx.doi.org/10.1017/s0043933909000191

[17] Thieme, O., Sonaiya, F., Rota, A., Guèye, F., Dolberg, F. and Alders, R. Defining family poultry production systems and their contribution to livelihoods; In: Decision tools for family poultry development; Animal Production and Health Guidelines No. 16; FAO: Rome, Italy, 2014; pp. 3-8.

[18] Otte, J., Nugent, R. and McLeod, A. (2004). “Transboundary Animal Diseases: Assessment of SocioEconomic Impacts and Institutional Responses;" FAO Livestock Policy Discussion Paper No. 9; Food and Agriculture Organization: Rome, Italy.

[19] Otte, J., Roland-Holst, D., Pfeiffer, D., Soares-Magalhaes, R., Rushton, J., Graham, J. and Silbergeld, E. "Industrial Livestock Production and Global Health Risks;" Pro-Poor Livestock Policy Initiative (PPLPI) Research Report, June 2007.

[20] Bravo-Baumann, H. (2000). "Genderand Livestock: Capitalisation of Experiences on Livestock Projects and Gender;" Working document; Swiss Agency for Development and Cooperation: Bern, Switzerland.

[21] Niamir-Fuller, M. (1994). "Women Livestock Managers in the Third World: A Focus on Technical Issues Related to Gender Roles in Livestock Production;" IFAD: Rome, Italy.

[22] IFAD. (2004). "Livestock Services and the Poor: A Global Initiative; Collecting, Coordinating and Sharing Experiences;" International Fund for Agricultural Development (IFAD): Rome, Italy.

[23] Bradley, F.A. A historical review of women's contributions to poultry production and the implications for poultry development policy. Proceedings 19th World's Poultry Congress, Vol. 2, Amsterdam, The Netherlands, 1992, pp. 693-696.

[24] Bhurtel, R. Women's participation in rural poultry development. Proceedings 20th World's Poultry Congress, Vol. 3, New Delhi, India, 1996, pp. 413-417.
[25] Khan, A.G. Women as a resource target for rural poultry production in India. Proceedings 10th European Poultry Conference, Vol. 2, Jerusalem, Israel, 1998, pp. 604-606.

[26] Rushton, J. and Ngongi S.N. (1998). Poultry, Women and Development: Old Ideas, New Applications and the Need for More Research; Food and Agriculture Organization of the United Nations: Rome, Italy.

[27] Chant, S. Towards a (re)-conceptualisation of the "feminisation of poverty": reflections on gender-differentiated poverty from The Gambia, Philippines and Costa Rica. In Chant, S. (ed.) International Handbook of Gender and Poverty; Concepts, Research, Policy; Edward Elgar Publishing:Northampton, MA, USA, 2010, pp. 111-116.

[28] Meinzen-Dick, R., Quisumbing, A., Behrman, J., Biermayr-Jenzano, P., Wilde, V. andNoordeloos, M. (2010). Engendering Agricultural Research.IFPRI Discussion Paper 973; IFPRI: Washington DC, USA.http://www.ifpri.org/publication/engenderingagriculturalresearch.

[29] Quisumbing, A.R. and Meinzen-Dick, R. (2001). Empowering Women to Achieve Food Security.

[30] FAO. (2010). Smallholder poultry production- livelihoods, food security and socio-cultural significance; by Kryger, K.N., Thomsen, K.A., Whyte, M.A. and Dissing, M. Smallholder Poultry Production; Paper No. 4; Food and Agricultural Organization, FAO:Rome, Italy.

[31] Ahlers, C., Alders, R.G., Bagnol, B., Cambaza, A.B., Harun, M.;,Mgomezulu, R., Msami, H., Pym, R., Wegener, P., Wethli, E. and Young, M. Improving village chicken production: a manual for field workers and trainers. In: ACIAR Monograph No. 139; 2009; p.194.

[32] Guèye, E.F. (2003). Gender issues in family poultry production systems in low-income food-deficit countries. American Journal of Alternative Agriculture, 18, 185195.https://doi.org/10.1079/AJAA200350.

[33] Jaitner, J., Sowe, J., Secka-Njie, E. and Dempfl E.L. (2001). Ownership pattern and management practices of small ruminants in The Gambiaimplications for a breeding programme. Small Ruminant. Research, 40(2), 101-108.

[34] Oluka, J., Owoyesigire, B.; Esenu, B. and Sssewannyana, E. (2005). Small stock and women in livestock production in the Teso Farming System region of Uganda. Small Stock inDevelopment 151.

[35] Okitoi, L.O., Ondwasy, H.O., Obali, M.P. and Murekefu, F. (2007). Gender issues in poultry production in rural households of western Kenya. Livestock Research for Rural Development19; Article \#17 http://www.lrrd.org/lrrd19/2/okit19017.htm.

[36] Mapiye, C.; Mwale, M.; Mupangwa, J.F.; Chimonyo, M.; Foti, R.; Mutenje, M.J. (2008). A research review of village chicken production constraints and opportunities in Zimbabwe. Asian-Australasian Journal of Animal Science, 21, 16801688.https://doi.org/10.5713/ajas.2008.r.07.

[37] Tadelle, D.; Ogle, B. (2001). Village poultry production system in the central high lands of Ethiopia. Tropical Animal Health and Production, 33, 521-537. https://doi.org/10.1023/A:1012740832558.

[38] Kusina, J., Kusina, N. and Mhlanga, J. A survey on village chicken losses: causes and solutions as perceived by farmers. Paper presented at the ACIAR Proceedings, Canberra, Australia, 2001; pp. 148-155.

[39] Dolberg, F. Poultry production for livelihood improvement and poverty alleviation. In: Thieme, O.; Pilling, D. (Ed), Poultry in the 21st Century: Avian influenza and beyond. Proceedings of the International Poultry Conference, Bangkok, Thailand, 5-7 November 2007.

[40] Muchadeyi, F., Sibanda, S., Kusina, N., Kusina, J. and Makuza, S. (2004). The Village Chicken Production System in Rushinga District of Zimbabwe. Livestock Research for Rural Development, 16. http://www.cipav.org.co/lrrd/lrrd16/06/much16040.htm.

[41] Alders, R.G. and Pym, R.A.E. (2009). Village poultry: still important to millions, eight thousand years after domestication. World's Poultry Science Journal, 65(02), 181-190.

[42] Guèye, E.F. (2005). Gender aspects in family poultry management systems in developing countries. World's Poultry Science Journal, 61, 39-46. https://doi.org/10.1079/WPS200440.

[43] FAO. (2004). Small-scale poultry production: technical guide. In FAO animal production and health manual \#1; Food and Agriculture Organizationof the United Nations: Rome, Italy. http://www.fao.org/docrep/008/y5169e/y5169e00.htm.

[44] Mason, K. (1998). Wives' economic decision-making power in the family: five Asian countries. In K. Mason (ed.) The Changing Family in Comparative Perspective: Asia and the United States; East-West Center: Honolulu, USA.

[45] Quisumbing, A.R. (2003). What have we learned from research on intra-household allocation? In A. Quisumbing (ed.) Household Decisions, Gender, and Development: ASynthesis of Recent Research; IFPRI: Washington DC, USA. 
[46] World Bank. (2001). Engendering Development: Through Gender Equality in Rights, Resources, and Voice;World Bank: Washington DC, USA.

[47] Wong, J.T., de Bruyn, J., Bagnol, B., Grieve, H., Li, M., Pym, R. and Alders, R.G.(2017). Small-scale poultry in resource-poor settings: a review. Global Food Security, 15, 4352.https://doi.org/10.1016/j.gfs.2017.04.003.

[48] Grown, C., Gupta, G.R. and Kes, A. (2005). Taking Action: Achieving Gender Equality and the Millennium Development Goals; Earthscan: London, UK.

[49] OECD. (2009). DAC Guiding Principles for Aid Effectiveness, Gender Equality and Women's Empowerment; Organization for Economic Cooperation and Development: Paris, France. http://www.oecd.org/social/gender-development/42310124.pdf

[50] SDC. (2007). "The Livestock Revolution: An Opportunity for Poor Farmers?" Inforesources Focus No. 1/07, Swiss Agency for Development and Cooperation (SDC): Bern,Switzerland.

[51] Upton, M. (2004). "The Role of Livestock in Economic Development and Poverty Reduction;” Pro-Poor Livestock Policy Initiative Working Paper 10; Food and Agriculture Organization: Rome, Italy.

[52] Fischer, E. and Qaim, M. (2012). Linking smallholders to markets: determinants and impacts of farmer collective action in Kenya. Food Security, 4, 441-453. https://doi.org/10.1007/s12571-012-0199-7.

[53] Baden, S. (1998). Gender issues in agricultural liberalization. Topic paper prepared for Directorate General for Development (DGVIII) of the European Commission. Bridge Report No. 41; Institute for Development Studies, Sussex University: Brighton, UK.

[54] Dolan, C. 2001. The "good wife": struggles over resources in the Kenyan horticultural sector. Journal of Development Studies, 37(3), 39-70.

[55] World Bank. (2012). World Development Report 2012; Gender Equality and Development; World Bank: Washington DC, USA.

[56] Guèye, E.F. (1998). Village egg and fowl meat production in Africa. World's Poultry Science Journal, 54, 73-86. http://dx.doi.org/10.1079/WPS19980007.

[57] Aklilu, A.H. (2007). Village Poultry in Ethiopia. Socio-technical analysis and learning with farmers. Ph.D. thesis, Wageningen University, Wageningen, The Netherlands.

[58] Njuki, J. Gender and livestock value chains in Kenya, Tanzania and Mozambique. Paper presented at the Workshop on Gender and Market Oriented Agriculture, Addis Ababa, Ethiopia, 31 January-2 February 2011.

[59] Sally, B. (1998). "Gender Issues in Agricultural Liberalisation;” Topic paper prepared for Directorate General for Development of the European Commission; Report No. 41; Institute of Development Studies: Brighton, UK.

[60] Hill, C. (2003). "Livestock and Gender: The Tanzanian Experience in Different Livestock Production Systems; A Glance at LinKS: LinKS Project Case Study No. 3;" FAO: Rome, Italy.

[61] Smith, L., Ramakrishnan, U., Ndiaye, A., Haddad, L.J. and Martorell, R. (2003). The Importance of Women's Status for Child Nutrition in Developing Countries. Research Report 131.

[62] KIT; Agri-ProFocus; IIRR. (2012). Challenging Chains to Change: Gender Equity in Agricultural Value Chain Development; KIT Publishers, Royal TropicalInstitute: Amsterdam, Netherlands.

[63] Kariuki, J., Njuki, J., Mburu, S. and Waithanji, E. Women, livestock ownership and food security; International Livestock Research Institute and International Development Research Centre: Nairobi, Kenya, 2013, pp. 95.

[64] FAO/Ministry of Agriculture and Rural Development, MARD/Agrifood consulting International, ACI. "Gender Analysis in Poultry Production in ChúcSontown, Chuong My District, HàTây Province and ChàLâ Commune, DuongMinhChàu District, TãyNinh Province." Power Point presentation at the workshop, The Future of Poultry Farmers in Vietnam after Highly Pathogenic Avian Influenza, Hanoi, Vietnam, March 8-9 2007.

[65] IFAD. (2007). Innovation in Women's Small-scale Poultry Activities; International Fund for Agricultural Development (IFAD): Rome, Italy.http://www.ifad.org/gender/learning/sector/agriculture/w_i.htm.

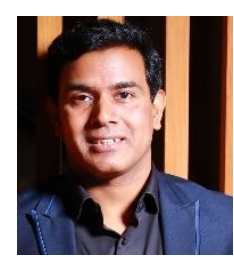

Soshe Ahmed an Associate Professor in the Department of Veterinary and Animal Sciences, University of Rajshahi, Bangladesh. He is a graduate of B.Sc. in Animal Husbandry and Master of Science in Poultry Science from Bangladesh Agricultural University.

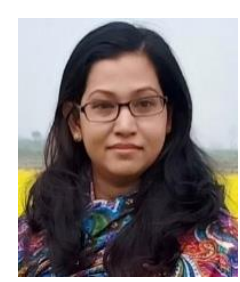

Maksuda Begum an Assistant Professor in the Department of Poultry Science, Faculty of Anima Science and Veterinary Medicine, Sher-e-Bangla Agricultural University. She is a graduate of B.Sc. in Animal Husbandry and Master of Science in Poultry Science from Bangladesh Agricultural University. She did her PhD from the same university.

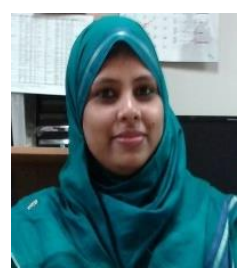

Afia Khatun an Associate Professor in the Department of Veterinary and Animal Sciences, University of Rajshahi, Bangladesh. He is a graduate of Doctor of Veterinary Medicine, and Master of Science in Pathology from Bangladesh Agricultural University. He did his PhD in Japan.

Md. R Gofuran Associate Professor in the Department of Veterinary and Animal Sciences, University of Rajshahi, Bangladesh. He is a graduate of Doctor of Veterinary Medicine, and Master of Science in Anatomy and Histology from Bangladesh Agricultural University. He did his PhD in Japan.

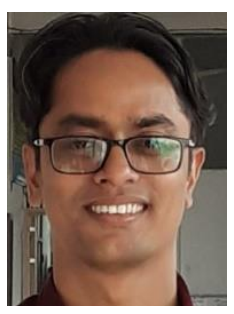

Md. TA Azadan Associate Professor in the Department of Veterinary and Animal Sciences, University of Rajshahi, Bangladesh. He is a graduate of Doctor of Veterinary Medicine from University of Rajshahi, and Master of Science in Microbiology and Hygiene from Bangladesh Agricultural University. He did his PhD in Japan.

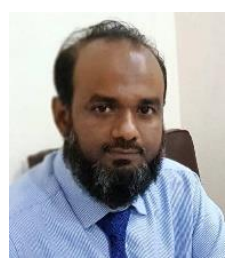

Aurangazeb Kabir an Associate Professor in the Department of Veterinary and Animal Sciences, University of Rajshahi, Bangladesh. He is a graduate of Doctor of Veterinary Medicine, and Master of Science in Medicine from Bangladesh Agricultural University. He did his PhD in Japan.

Tasmin S. Haque is a graduate from the Department of Anthropology, and Master in Social Science from the University of Rajshahi, Bangladesh. 